Original Research Paper

\title{
Integrations of Seismic Data, Petro-physical Evaluation and Reserve Estimation in Fimkassar Oil Field of Eastern Potwar, Pakistan
}

\author{
${ }^{1}$ Muhammad Ishfaque, ${ }^{2}$ Hafeez Ur Rehman, \\ ${ }^{3}$ Bilal Khalid, ${ }^{4}$ Syed Habib, ${ }^{1}$ Umair Fakhar and ${ }^{5}$ Sudip Chakarborti \\ ${ }^{I}$ Institute of Geology, The University of Azad Jammu and Kashmir, Muzaffarabad, Pakistan \\ ${ }^{2}$ Dipartimento di Biologia, Ecologia e Scienze della Terra, Universita della Calabria, Italy \\ ${ }^{3}$ Department of Metrology, Comsat Institute of Information Technology, Islamabad, Pakistan \\ ${ }^{4}$ Pakistan Petroleum Limited, Pakistan \\ ${ }^{5}$ Masdar Institute, iWater, Department of Chemical and Environmental Engineering, Abu Dhabi, UAE
}

Article history

Received: 21-02-2017

Revised: 28-02-2017

Accepted: 13-04-2017

Corresponding Author: Muhammad Ishfaque Institute of Geology, The University of Azad Jammu and Kashmir, Muzaffarabad, Pakistan

Email: m.ishfaque21@hotmail.com

\section{Introduction}

The Fimkassar oil field is the concession area of Oil and Gas Development Company Limited (OGDCL). The Fimkassar oil field is located in the eastern part of the Potwar sub-basin and it is about $75 \mathrm{Km}$ away from SW of Islamabad as shown in Fig. 1. The Upper Indus Basin is bounded by Soan syncline in the north, Salt Range in the south, Jhelum Fault in the east and Kalabag Fault in the west shown in Fig. 2 (Aamir and Siddiqui, 2006). The Potwar area is one of the oldest regions of oil production in Pakistan Khalid et al. (2015). The Potwar sub-basin is present in northern Pakistan at the western foothills of the Himalayas. It includes the Jhelum Plain, the Potwar Plateau and the Salt Range. The MBT and

\begin{abstract}
In upper Indus basin Potwar plateau is a successful exploration area for hydrocarbon. The study area is consisting of Fimkassar oil field and research data is obtained from Land Mark Resources with the special permission of Director General of Petroleum Concession Ministry of petroleum and natural resources Islamabad. The study area consists of well\#1 occurrence of hydrocarbon in deeper horizon of sedimentary basin. The Chorgali Formation to delineate promising location for test drilling into Chorgali Formation. The methodology adopted to achieve the reserves estimation includes the measurements for the shale volume by using Gamma SP method, Saturation of water in the zone of reservoir and Hydrocarbon saturation using Archie equation. Time structure maps of the reflectors will be produced using two-way time of the reflectors. Time structure map is converted into depth contour map and get area for reserve estimation.
\end{abstract}

Keywords: Seismic Integration, Petrophysical Evaluation, Reserve Estimation in Fimkassar Oil Field salt range thrust mark the northern and southern boundaries of Potwar sub-basin. While Jhelum faults, the Indus river and the Kalabagh dextral fault mark the eastern and western boundaries respectively (Moghal et al., 2007). Structurally, Potwar Sub-basin is a highly complex area and mostly surface features do not reflect subsurface structures due to presence of decollement at different levels (Moghal et al., 2007). The latitude and longitude of the study area is $33^{\circ} 4^{\prime} 33^{\prime \prime} \mathrm{N}$ and $72^{\circ} 56^{\prime} 46^{\prime \prime} \mathrm{E}$ respectively and its elevation from mean sea level is about 511 meters. Fimkassar oil field produces from an anticline of dolomitized fractured limestones of the Eocene Sakesar Limestone and Chorgali Formation. The field has been studied in detail because of its low production history. Gulf Oil Company drill first discovered well in this field 
but because of low productivity ( 20 barrels/day), the well was sold to the OGDCL. OGDCL drilled five wells on the crest of Fimkassar structure that were give production (4,000 barrels/day) or became dry.

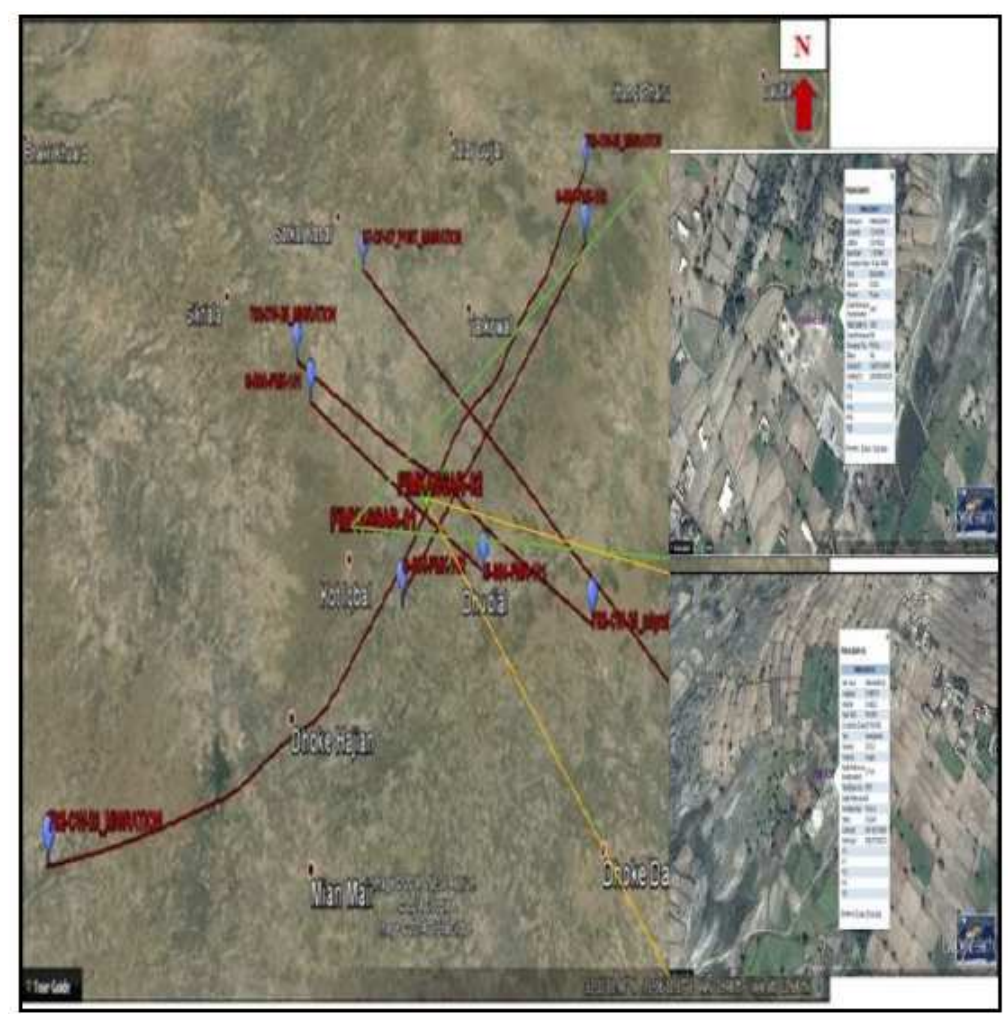

Fig. 1. Satellite image of Fimkassar area showing seismic lines and wells Fig. 2. Tectonic map of Potwar Plateau also shows the of study area. (Google Earth)

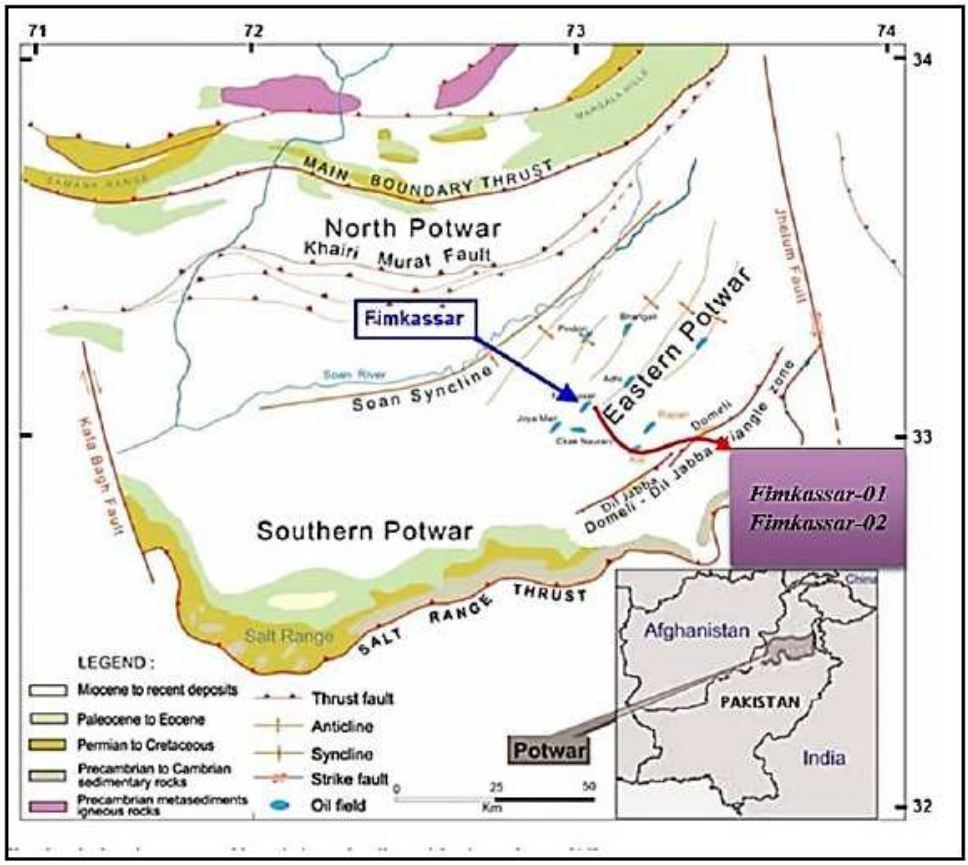

Fig. 2. Tectonic map of Potwar Plateau also shows 


\section{Methodology}

The methodology flow chart as shown in Fig. 3 to proceed the research. There are two methods of interpretation of seismic data. In the first method, the interpretation is carried through in the areas of significant well control. Here the information of well is first tied with the seismic then we check continuity between wells for areas of interest. While the interpretation of the second pattern areas do not have well and seismic data to provide both the definition of the structure and estimate depositional environments. As more and more material involved into the interpretation, the outcomes becomes better. The mixing of the seismic data with geological data, whether from a well, surface, or subsurface sources (e.g., fault traces or geologic contacts) and include identifying reflectors and make relations to wells or surface features (Dobrin and Savit, 1988). There are two main approaches to the interpretation of the seismic section which is Stratigraphic and Structural analysis. The following step involve in seismic data interpretation which is Loading LAS and SEG-Y file data on kingdom 8.4 software and creating base map of seismic line, Creating synthetic seismogram by Converting sonic transit times to velocity by taking the reciprocal and overlay seismic section on it, Examine the seismic section is one of the most significant step to take enough time examining the section, Picking the reflector on the basis of best coherency and continuity of amplitude of waves and coloring the different reflector with different colors, Identification of structural features on seismic section on the basis of geology of the area and the diffractions shown on the section. Structural and Stratigraphic analysis are the two main approaches to interpret the line. Here we are considering the structural approach, Tying the seismic lines to get a better and real picture, creating grid of the seismic section, Creating Time-structure map and depth contour map of the selected lines. The data is presented on the map in the form of contours representing actual reflection times, or depth. Petrophysics is the study of reservoir and cap rock properties and their interaction with fluid (Gases, Hydrocarbons and aqueous solutions) based on fundamental methods of physics, chemistry and mathematics. The petrophysical study of reservoir and cap rock properties by laboratory testing or wireline well logging (Buryakovsky et al., 2012). Petrophysical interpretation is the study of wireline logs. Different rock parameters have been used to calculate the volume of shales, porosity, hydrocarbon saturation, water saturation, net pay thickness and lithology (Rider, 2002).

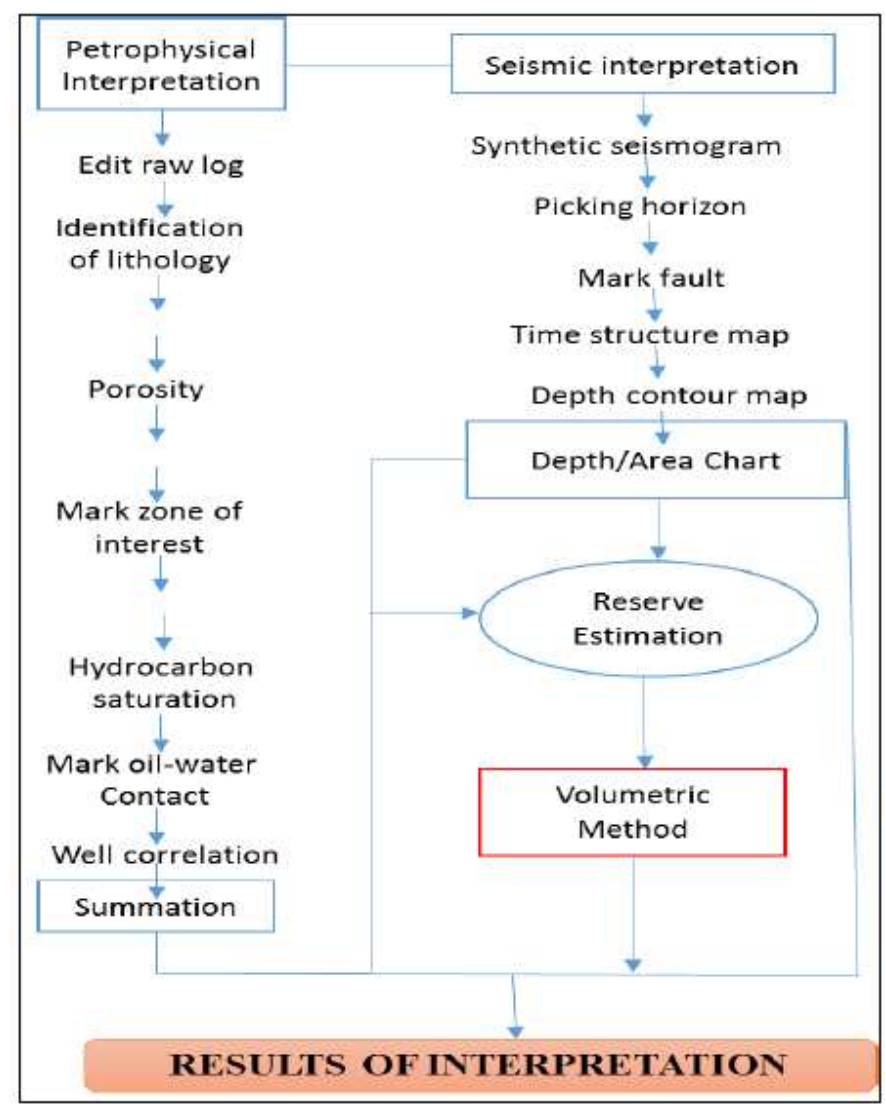

Fig. 3. Well data Interpretation flow Chart 


\section{Determination of Volume of Shale (Vsh)}

Because shale emits more radiation than carbonate or sand, gamma ray logs can be used to calculate volume of shale in porous reservoirs. The volume of shale can then be useful for analysis of shaly sands. Calculation of the gamma ray index is the first step to determine the shale volume from a gamma ray log (Schlumberger, 1974):

$$
I G R=G R_{\mathrm{log}}-G R_{\text {min }} / G R_{\text {max }}-G R_{\text {min }}
$$

$I G R=$ Gamma ray index

$G R_{\log }=$ Gamma ray reading of formation

$G R_{\min }=$ Minimum gamma ray (carbonate or clean sand)

$G R_{\max }=$ Maximum gamma ray (shale)

\section{Density Porosity}

Density porosity has been calculated with the help of following formula (Hilchie, 1978):

$$
\varphi_{D}=\rho_{m}-\rho_{b} / \rho_{m}-\rho_{f}
$$

Where:

$$
\begin{aligned}
& \rho_{m}=2.71 \mathrm{gm} / \mathrm{cm}^{3} \\
& \rho_{f}=1 \mathrm{gm} / \mathrm{cm}^{3} \\
& \rho_{b}=\log \text { Response in zone of interest }
\end{aligned}
$$

\section{Total Porosity}

Total porosity has been calculated by the help of following formula (Schlumberger, 1974):

$$
\Phi_{T}=\Phi_{D}+\Phi_{N} / 2
$$

Where:

$\Phi_{T}=$ Total porosity

$\Phi_{D}=$ Density porosity

$\Phi_{N}=$ Neutron porosity

\section{Effective Porosity}

Effective porosity has been calculated with help of the following the formula (Hilchie, 1978):

$$
\Phi_{E}=\Phi_{T} \times\left(1-V_{s h}\right)
$$

Where:

$\Phi_{E}=$ Effective porosity

$\Phi_{T}=$ Total porosity

$V_{s h}=$ Volume of shale

\section{Sonic Porosity}

Sonic porosity has been calculated with help of the following the formula (Wyllie et al., 1958):

$$
\Phi_{S}=\Delta T-\Delta t_{\text {mat }} / \Delta T_{f}-\Delta t_{\text {mat }}
$$

Where:

$$
\begin{array}{ll}
\Phi_{S} & =\text { Sonic porosity } \mu \mathrm{s} / \mathrm{ft} \\
\Delta_{T} & =\mathrm{Log} \text { response } \\
t_{\text {mat }} & =47 \\
\Delta T_{\text {fluid }} & =189
\end{array}
$$

\section{Water Saturation ( $S w)$ Determination}

Water saturation has been calculated with help of the Archie's Equation (Archie, 1942):

$$
\sqrt{\sqrt{S_{w}}=\sqrt{ }\left(a / \Phi^{m}\right) x\left(R_{w} / R_{t}\right)}
$$

Where:

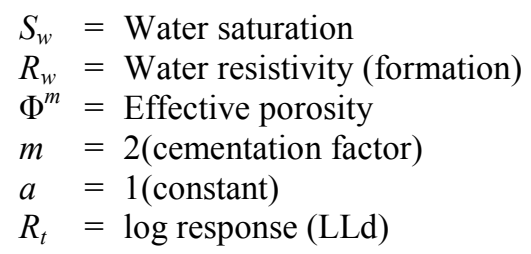

$R_{w}$ has been calculated with help of the following formula:

$$
R_{w}=\Phi^{2} \times R_{t}
$$

Where:

$\Phi=$ Porosity in clean zone

$R_{t}=$ Observed LLd curve in clean zone

\section{Saturation of Hydrocarbon}

It is denoted as $S_{h c}$. Saturation of hydrocarbon is calculated by given formula below (Schlumberger, 1974):

$$
S_{h c}=1-S_{w}
$$

$S_{w}=$ Saturation or water

\section{Cut Off}

This process is similar to filtering of seismic data. First we define the criteria for reservoir and nonreservoir, which process following factors. For reservoir following criteria is followed:

- Porosity $(\varphi)>10 \%$

- Volume of shale (V Shale) $<25 \%$

- Water saturation $(\mathrm{Sw})<75 \%$

Volumetric method is used to determine the amount of oil in place using the size of the reservoir, as well as the physical properties of the rocks and fluids. The 
recovery factor is assumed using the expectation of areas with similar characteristics. The recovery factor of oil fields all over the world, ranging from 10-60\%, but somewhere in the tour is about $80 \%$. The first condition in the volumetric method is to determine the size of the rock bearing potential oil and gas. This amount is given by the product of the accumulation of hydrocarbons and means the total thickness of the reservoir above the oil-water contact area represents the total average of the size of the reservoir is likely to be productive. Static volumetric method of oil and gas in place measure. The accuracy of volumetric method relies on data, such as porosity, net pay thickness range areal and hydrocarbon saturation. Uses a map of the line is equal to the depth to calculate the size of the bulk of the water from the reservoir. By looking at the average porosity and hydrocarbon saturation means of net pay section that the estimated size of the oil and gas in place. Use a software program reserve estimate of 5.3 version that works on the principle of volumetric method. The program requires some parameter which is based on the results of seismic evaluation and Petrophysic which is thickness of reservoir, Spill point, Degree of fill, Net-to-gross, Porosity, SW, Net-to-gross (fracture), Porosity (fracture), SW (fracture), Formation volume factor (B), Oil recovery factor, Oil recovery factor (fracture) and Area. These parameters are used to calculate prospect in reserve estimation program. The basic calculation in REP determines the in-place and recoverable reserves in a field or prospect. The equation is given below:

$$
\begin{aligned}
& \text { Re server }=G R V \times \text { P orosity } \\
& \times \text { Net }- \text { to }- \text { Gross } \times(1-S w) \times F V F \times R F
\end{aligned}
$$

$\begin{array}{ll}\text { Where: } & =\text { The gross reservoir volume } \\ \text { GRV } & =\text { The field average porosity } \\ \text { Porosity }= & \text { The field average net-to-gross ratio } \\ \text { Net-to-gross }= & \text { The field average water saturation - (1- } \\ \mathrm{SW} & \mathrm{Sw}) \text { is the hydrocarbon saturation } \\ = & \text { The reciprocal oil or gas Formation } \\ & \text { Volume Factor (FVF for oil is } 1 / \mathrm{Bo}, \text { for } \\ & \text { gas it is the gas expansion factor) } \\ = & \text { The recovery factor }\end{array}$

\section{Results}

Kingdom 8.4 was used for seismic interpretation in which upload the SEG-Y data and create a seismic base map using Seismic line as shown in Fig. 4. The sonic $\log$ and depth data was used to construct a timedepth chart and a synthetic seismogram was generated as shown in Fig. 5. Synthetic was prepared using wells $\log$ data of Fimkassar 1 and 2. Synthetic was matched with surface seismic data and top of Eocene Chorgali Formation was marked. Similarly, Sakesar Limestone and Patala Formation were marked and adjusted on the basis of thickness. The interpretation of the study area show that triangular zone is marked on seismic section and thrust fault and snake head structure present in the area as shown in Fig. 6. Structure of study area is a fault bounded from southeast and three-way closure toward NW $>$ SE side over all it is a fault bounded anticlinal feature. Five line have been choosing to construct the time structure map of top Eocene. All time against shot point is taken, the latitude and longitude of each shot point were already given in SEG-Y file and time grid is generated as shown in Fig. 7. Time grid was transferred into depth using single velocity component or constant velocity. The formula is used to calculate depth which is given as:

$$
S=V T / 2
$$

Where:

$S=$ Distant

$V=$ Velocity

$t=$ Time

Here we take time in millisecond for this purposes we multiply given formula with 1000 .

The velocity and time is known with northing and easting value by multiplying both the value in software and calculate depth. All data was save in AVO layer form in software and generated depth contour map as shown in Fig. 8. The depth on the contour map is in meter $(\mathrm{m})$. Now we calculate depth and area from contour map which is helpful for reserve estimation. The depth area chart is given below in Table 1 .

Petrophysical interpretation of Fimkassar well 1 and 2 done successfully shown in Fig. 9 and 10. The thickness of pay zone in Fimkassar well no 1 Chorgali Formation varies from Fimkassar well no 2. The thickness of Chorgali Formation in well no 1 is $62 \mathrm{~m}$ while the thickness of Chorgali Formation in Fimkassar well no 2 is $44 \mathrm{~m}$. Petrophysical analysis shows that in Fimkassar well 01 volume of shale is $21 \%$, porosity is $13 \%$ and water saturation is $53 \%$ similarly in Fimkassar well 02 volume of shale is $24 \%$, porosity is $16 \%$ and water saturation is $44 \%$. Petrophysical analysis show that Chorgali Formation is acting as a good hydrocarbon potential bearing rock. Pay zone thickness in Fimkassar well 01 is $11.31 \mathrm{~m}$ and similarly in Fimkassar well 02 it is 8.63 m. Oil-water contact marked in Fimkassar well 01 is at $2957 \mathrm{~m}$ depth and below this depth no oil is present in the well where as in Fimkassar well 02 it is marked at a depth of $2992 \mathrm{~m}$ and below this oil and water both 
are present in Sakesar Formation. The water-oil contact is marked in Fimkassar well 01 at the depth of $2957 \mathrm{~m}$ in Sakesar Reservoir. In the Sakesar Reservoir at the depth $2957 \mathrm{~m}$ well contain hydrocarbon in liquid form but below $2957 \mathrm{~m}$ in Fimkassar 01 well contained water. Below $2957 \mathrm{~m}$ no oil reserve is present. Similarly, in Fimkassar 02 water-oil contact is marked at the depth of $2992 \mathrm{~m}$ in Sakesar Reservoir. In Fimkassar 02 above $2992 \mathrm{~m}$ total hydrocarbon reserve in well and below this depth water and oil both liquid is present at the depth of $3070 \mathrm{~m}$ depth. The water oil contact shown below in Fig. 11 and 12. Correlation is comparing or matching of same rock unit of same ages. Several similar sections are correlated on the basis of either lithology or time (Evenick, 2008). There are two type of Correlation which is Structural Correlation and Stratigraphic Correlation. Structural correlation is used to interpret the structure like folds and faults of the borehole. But due to high deformation and tectonic activity structural correlation is not possible. Stratigraphic correlation is generally used for interpretation of the deposition of formations of specific time periods by considering a top of any formation of two wells as datum line. The top of Chorgali Formation of two well is considered as datum line. The total depth of Fimkassar 01 well is $3071 \mathrm{~m}$. The rock units range from MiocenePleistocene-Pliocene Siwalik-Murree shown in Fig. 13. Fimkassar 02 ranges from Pliocene Nagri, Chinji Kamilal and Murree formation of Miocene Chorgali and Sakesar of Eocene Patala Formation of Paleocene age. The total depth of this well is $3067 \mathrm{~m}$. Shale unit mark in correlation of Fimkassar 1 and between Chorgali Formation and Sakesar Limestone at the top depth of Sakesar. Similarly, in zone 2 blocky Limestone is marked between the Sakesar limestone and Patala Formation in Fimkassar 1 and 2 as shown in stratigraphic cross section Fig. 14 of Fimkassar wells.

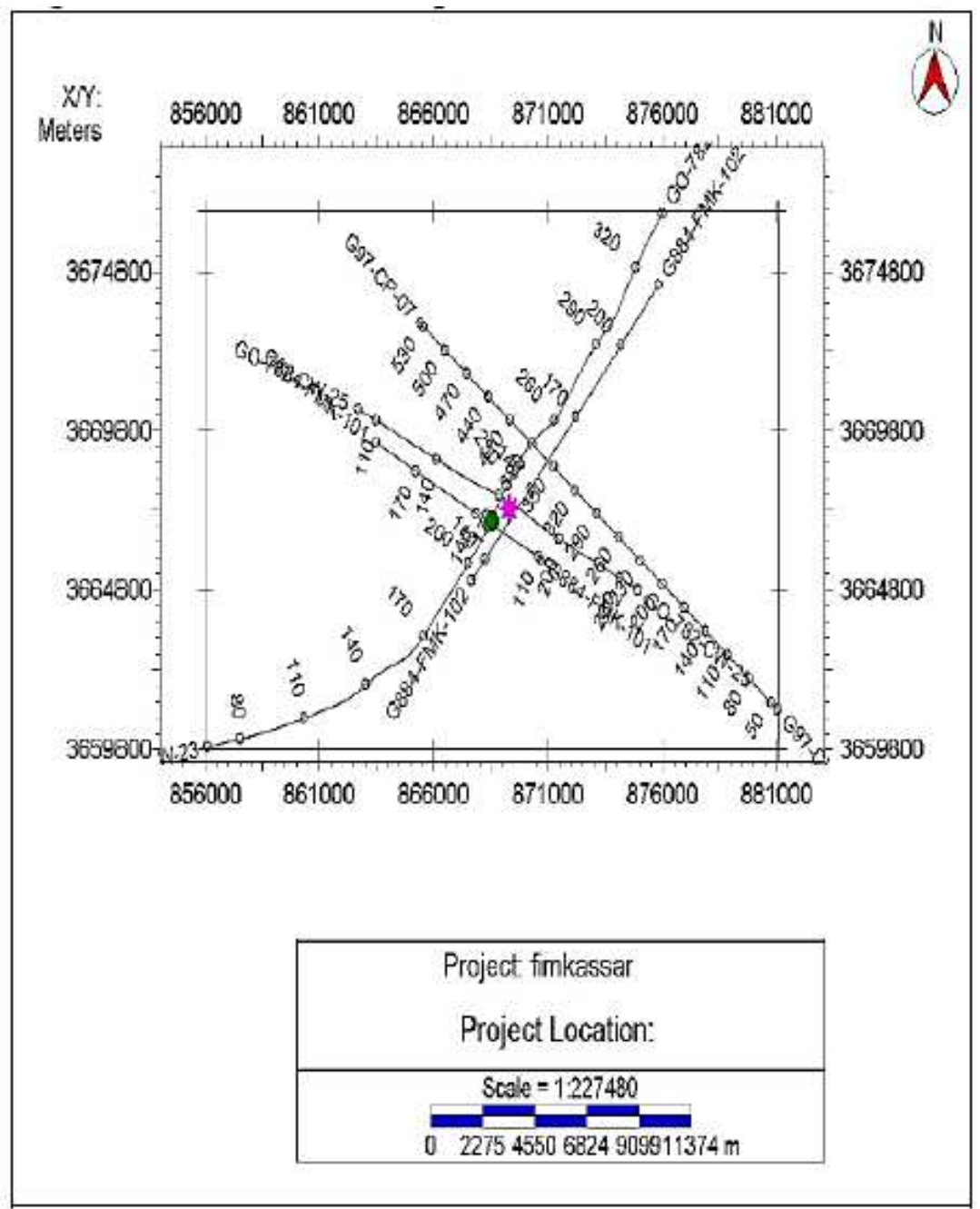

Fig. 4. Base map created up to scale in $42^{\circ} \mathrm{N}$ zone of Universal Transverse Mercator system in Kingdom software 


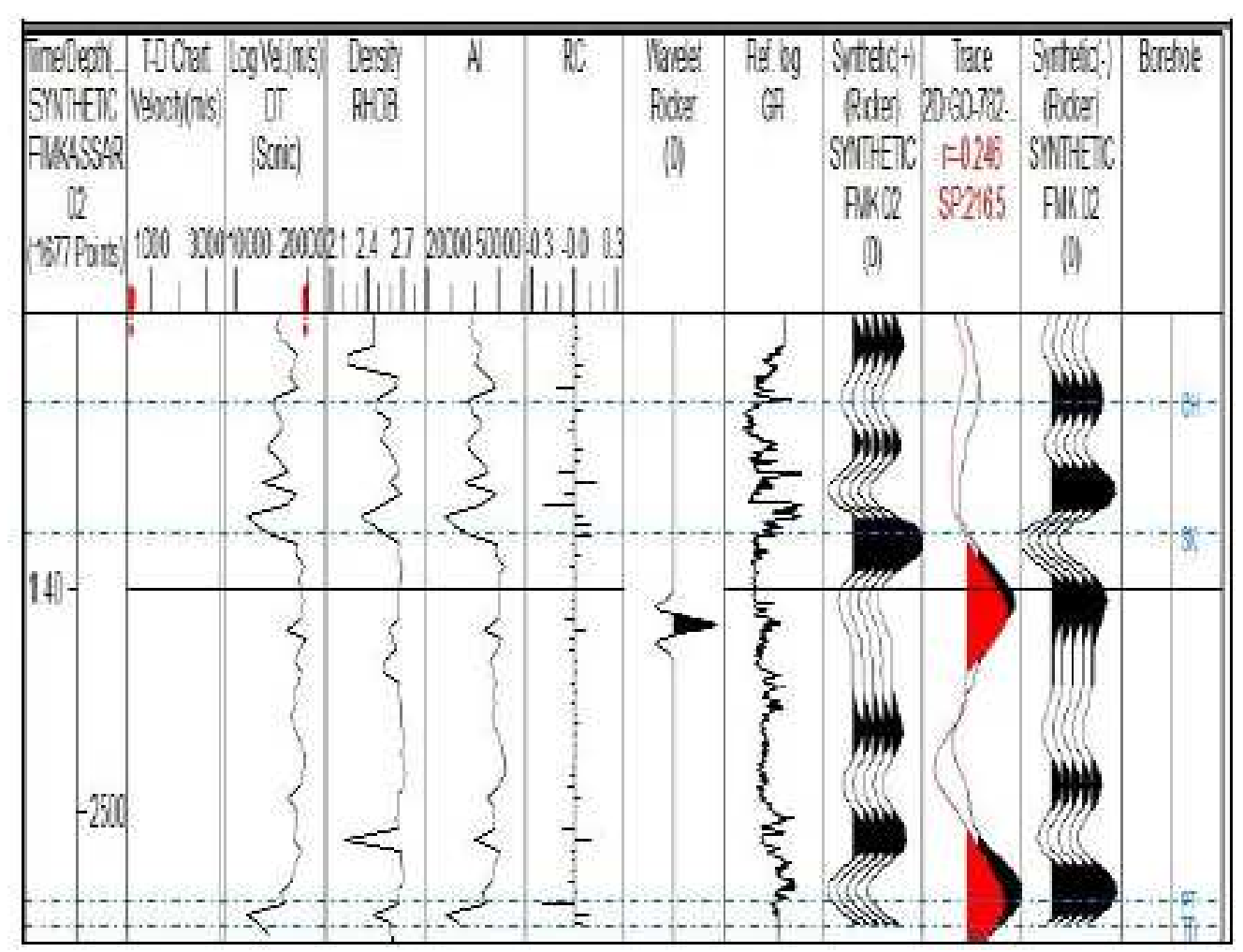

Fig. 5. Synthetic seismogram of Fimkassar well \#2

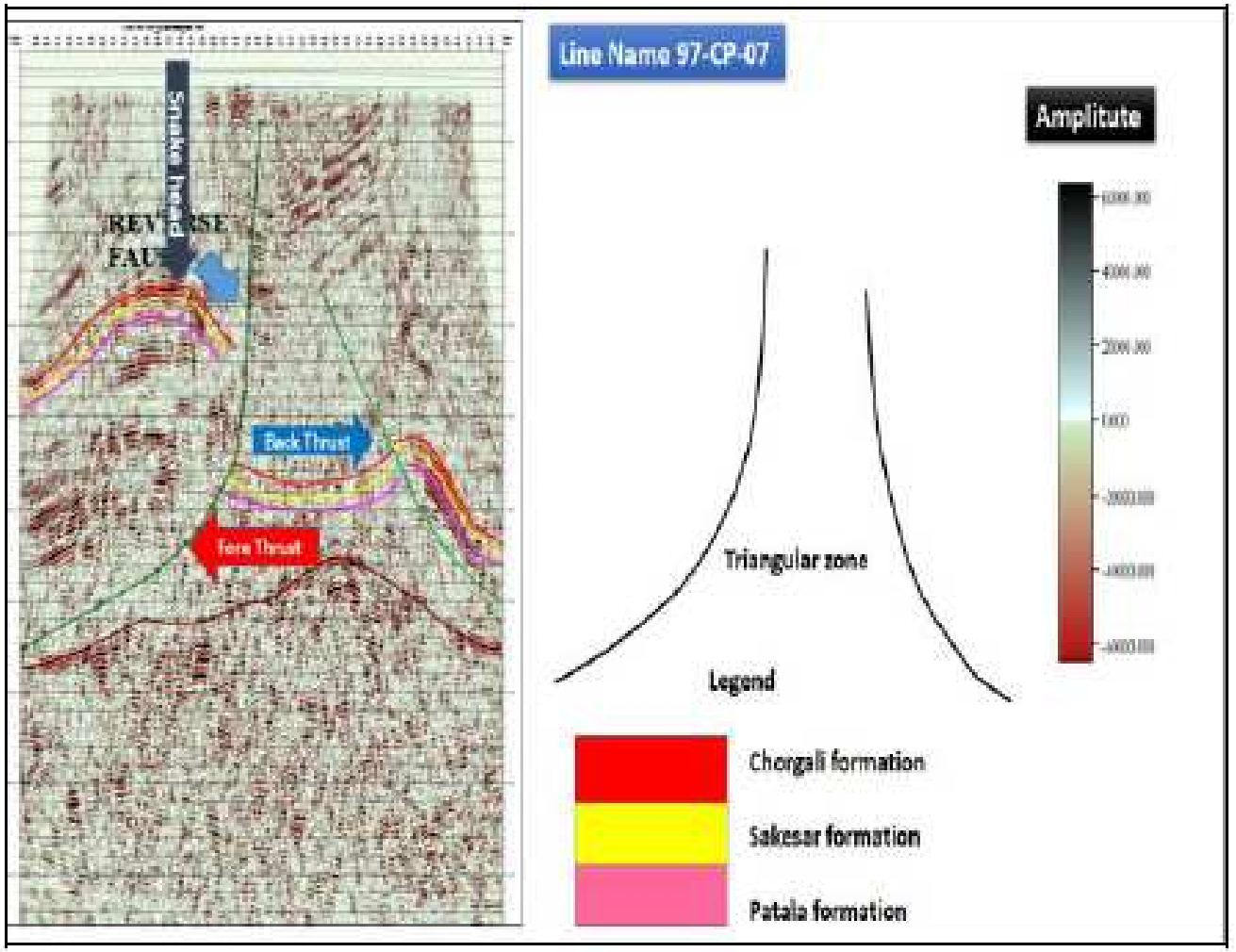

Fig. 6. Interpretated seismic section show structure of the area 


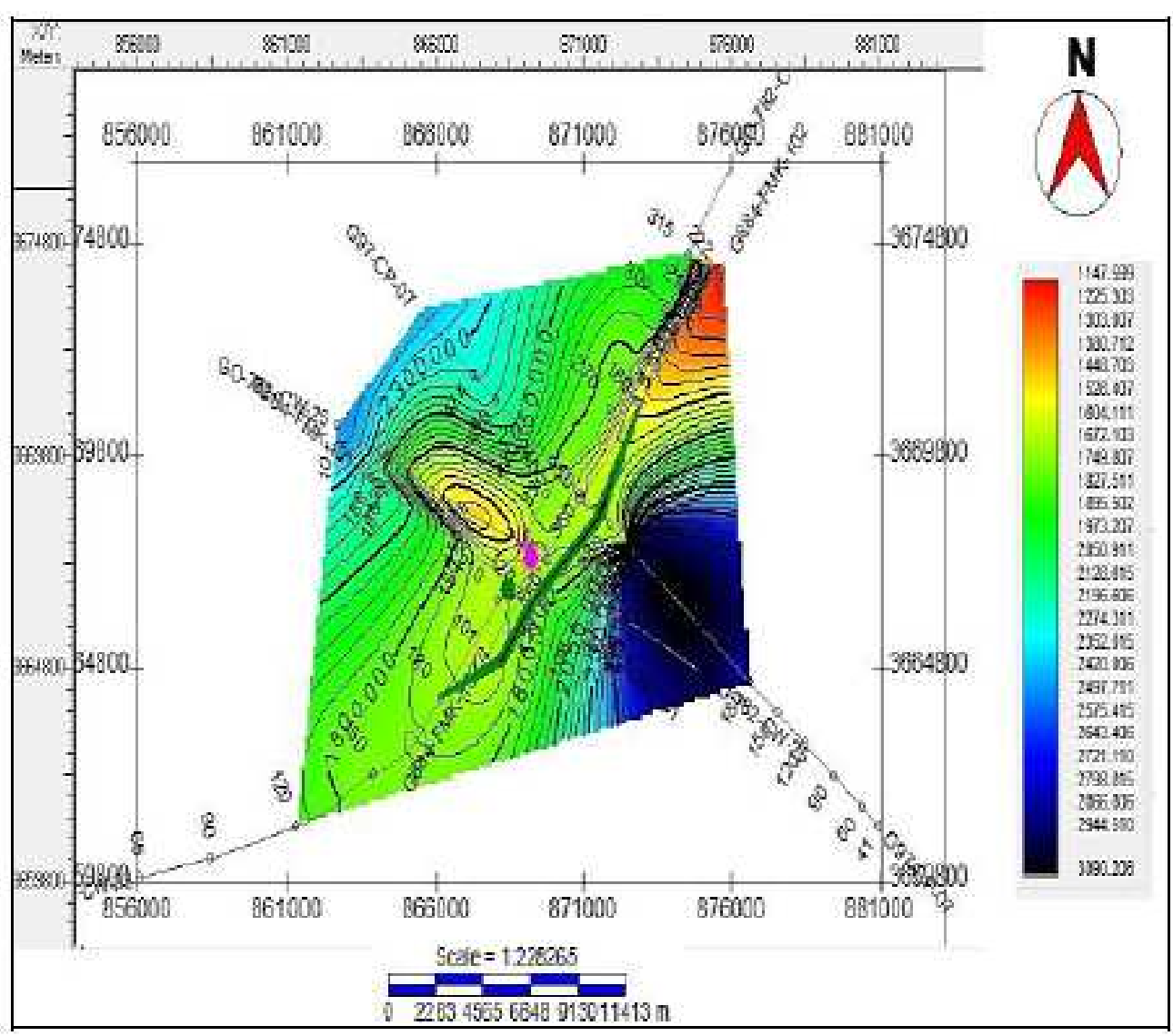

Fig. 7. Time structure map of Chorgali Reservoir

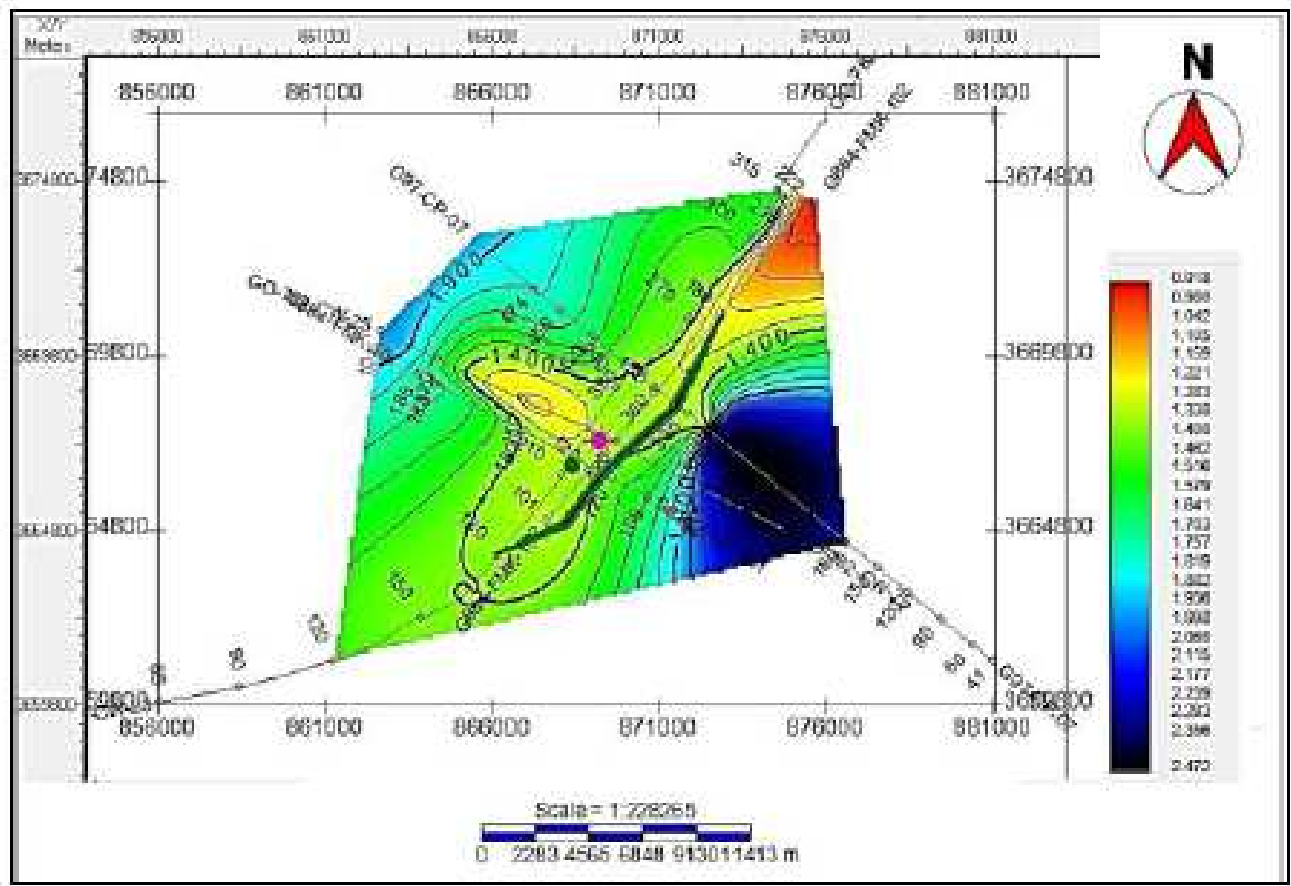

Fig. 8. Depth Contour map of Chorgali Reservoir 


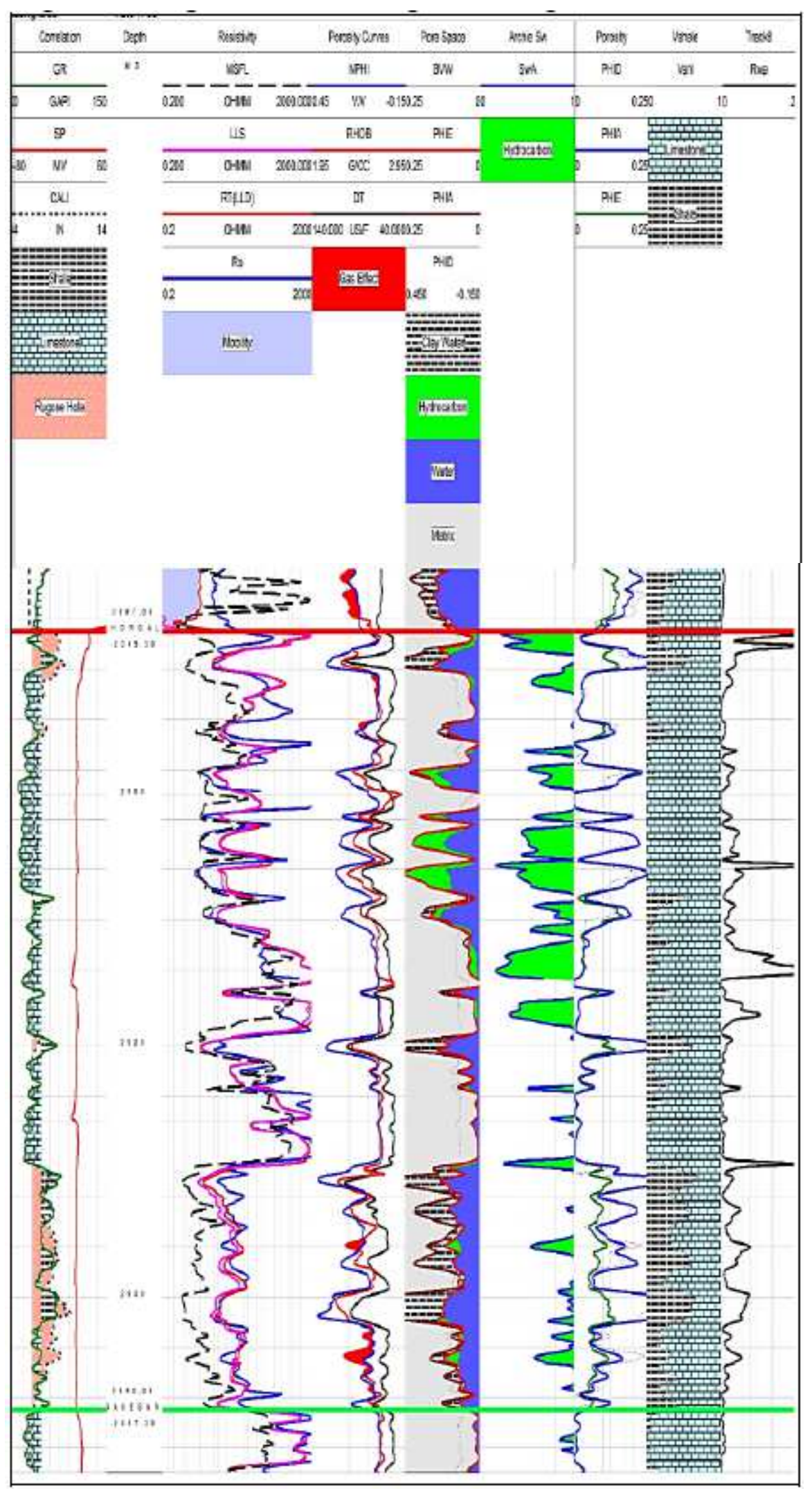

Fig. 9. Show interpreted well log of Chorgali Reservoir in well Fimkassar 01 


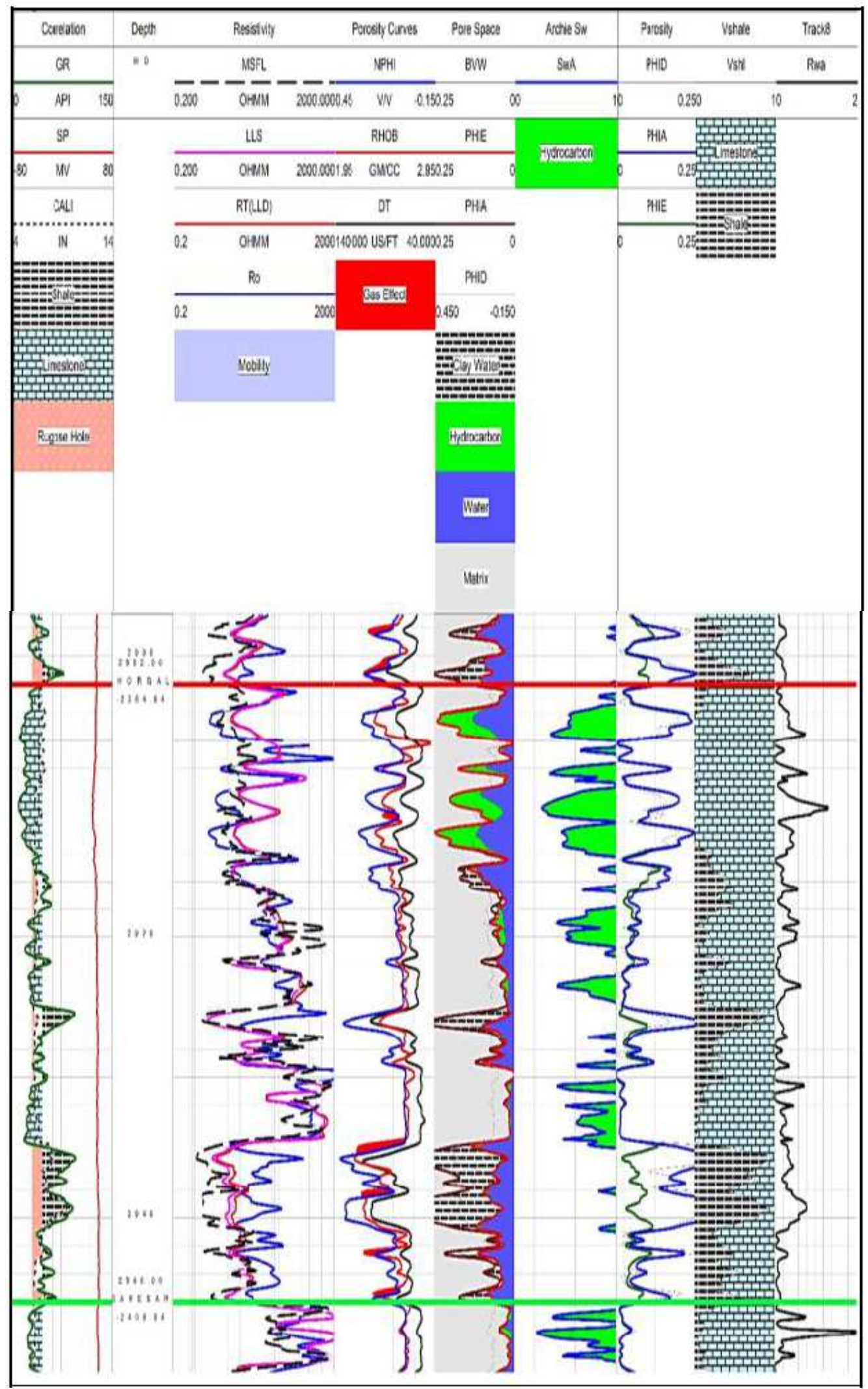

Fig. 10. Show interpreted well log of Chorgali Reservoir in well Fimkassar 02 


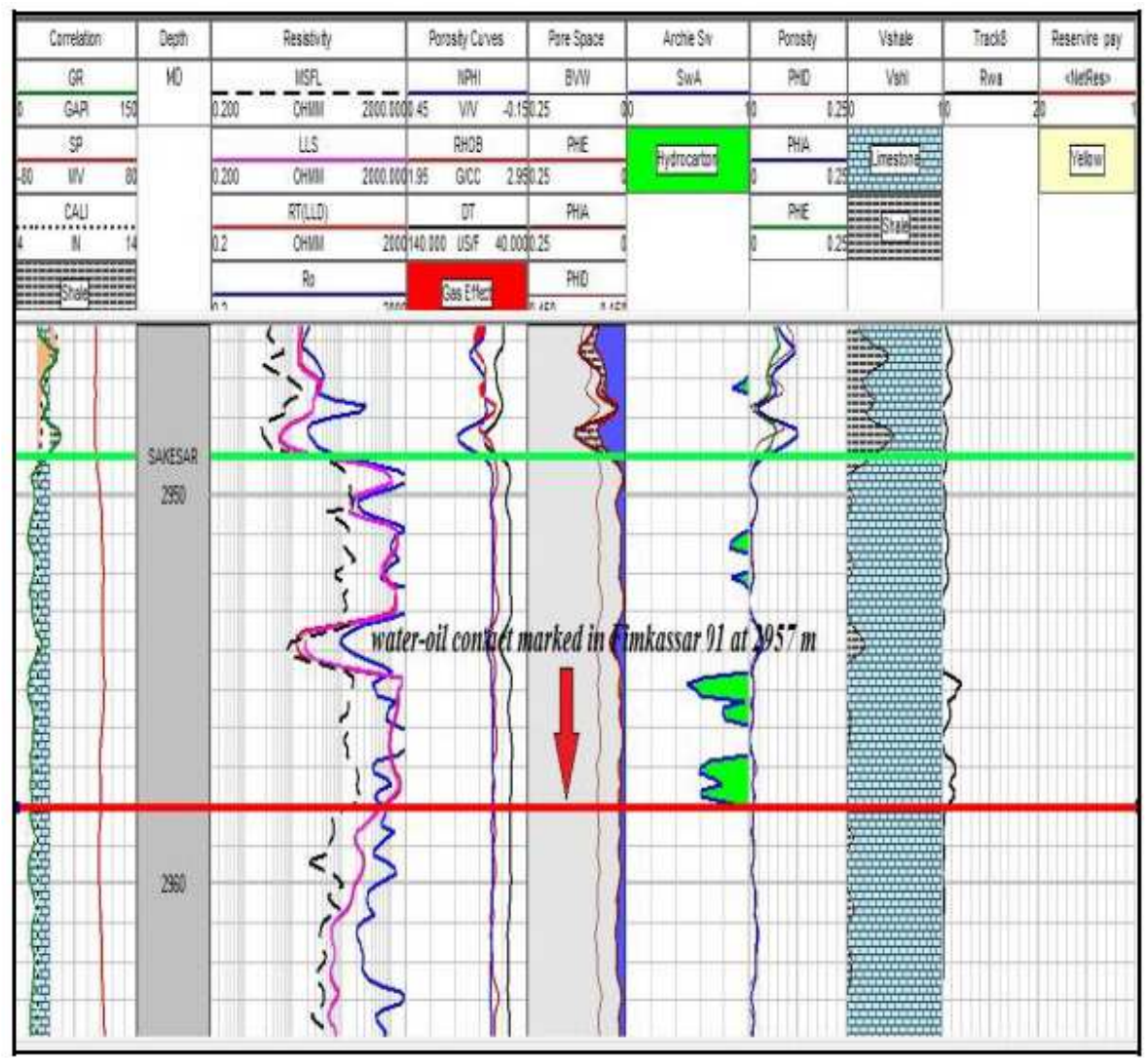

Fig. 11. Show that water-oil contact in well log of Fimkassar 01

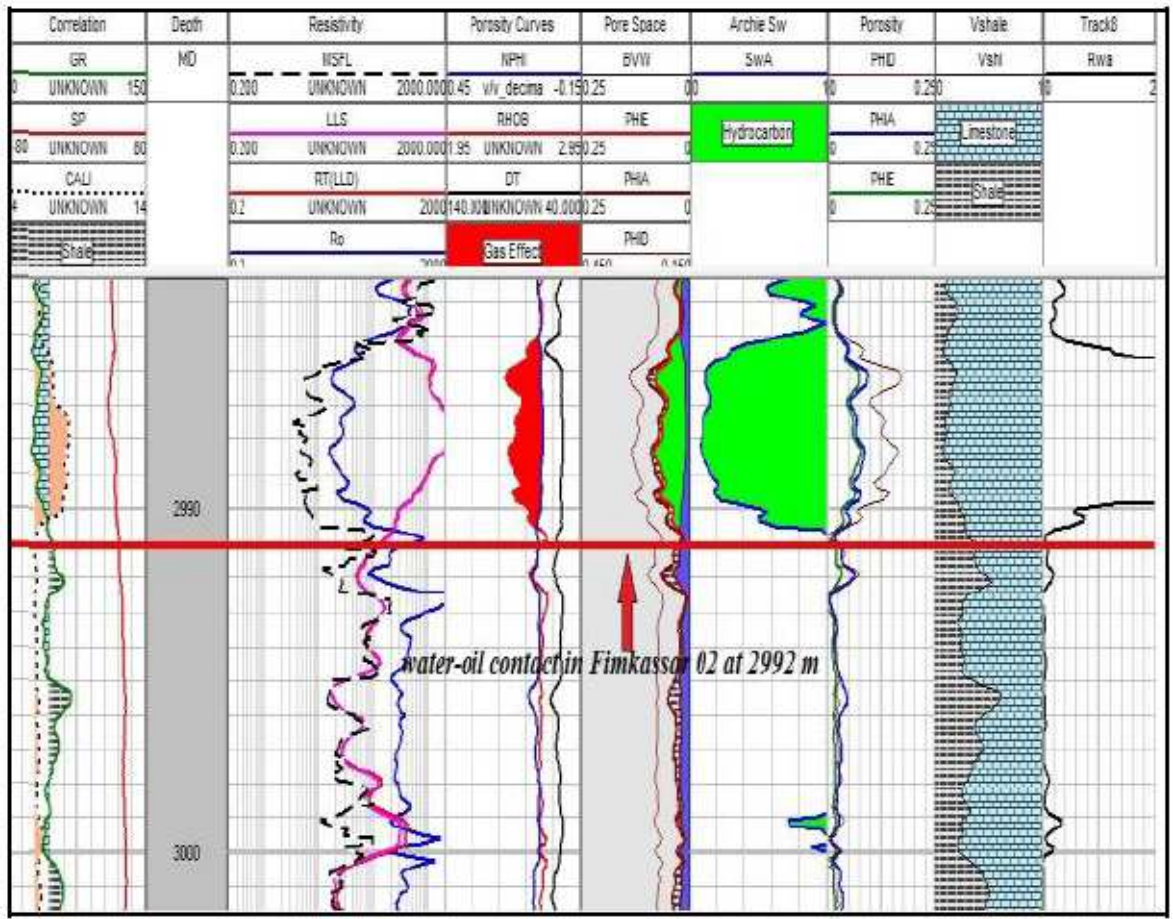

Fig. 12. Show that water-oil contact in well log of Fimkassar 02 


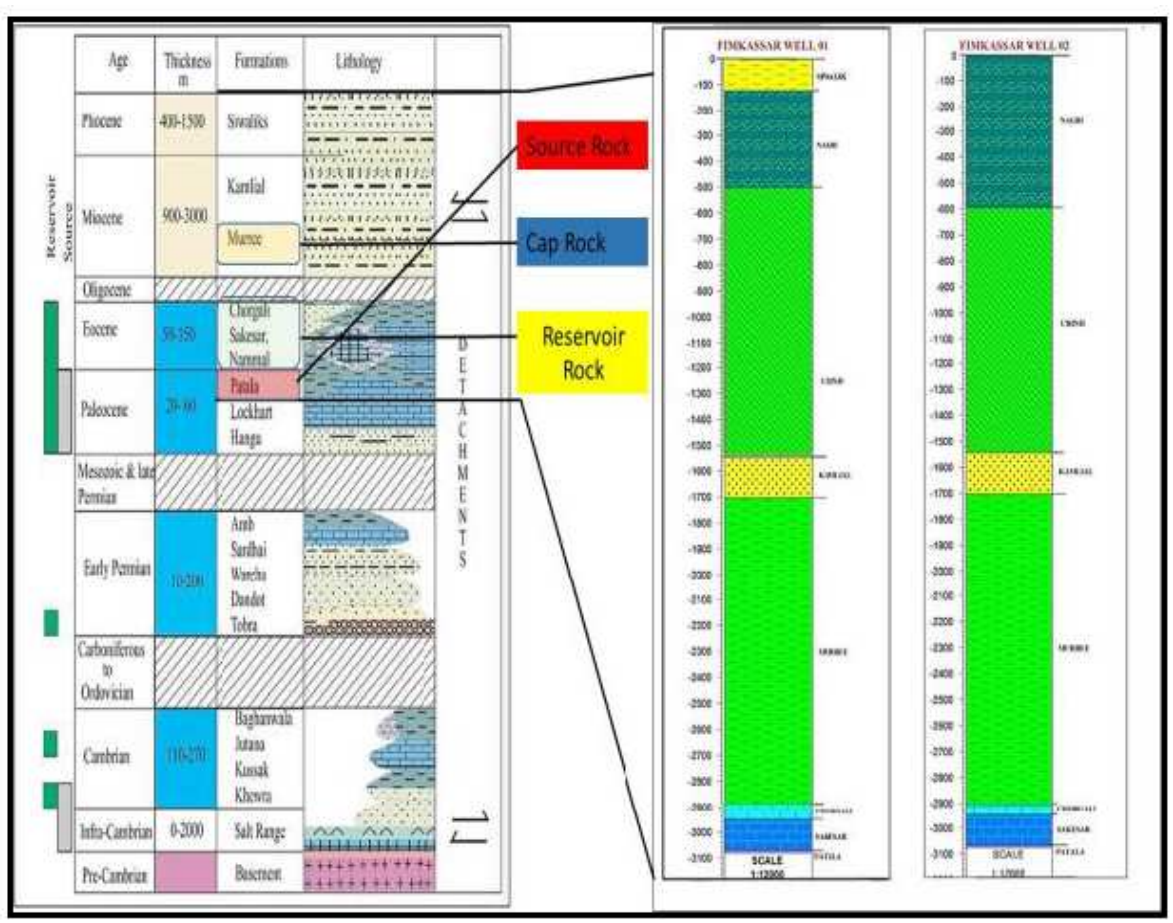

Fig. 13. Stratigraphic chart and Interpreted lithology of Fimkassar well 1 and 2

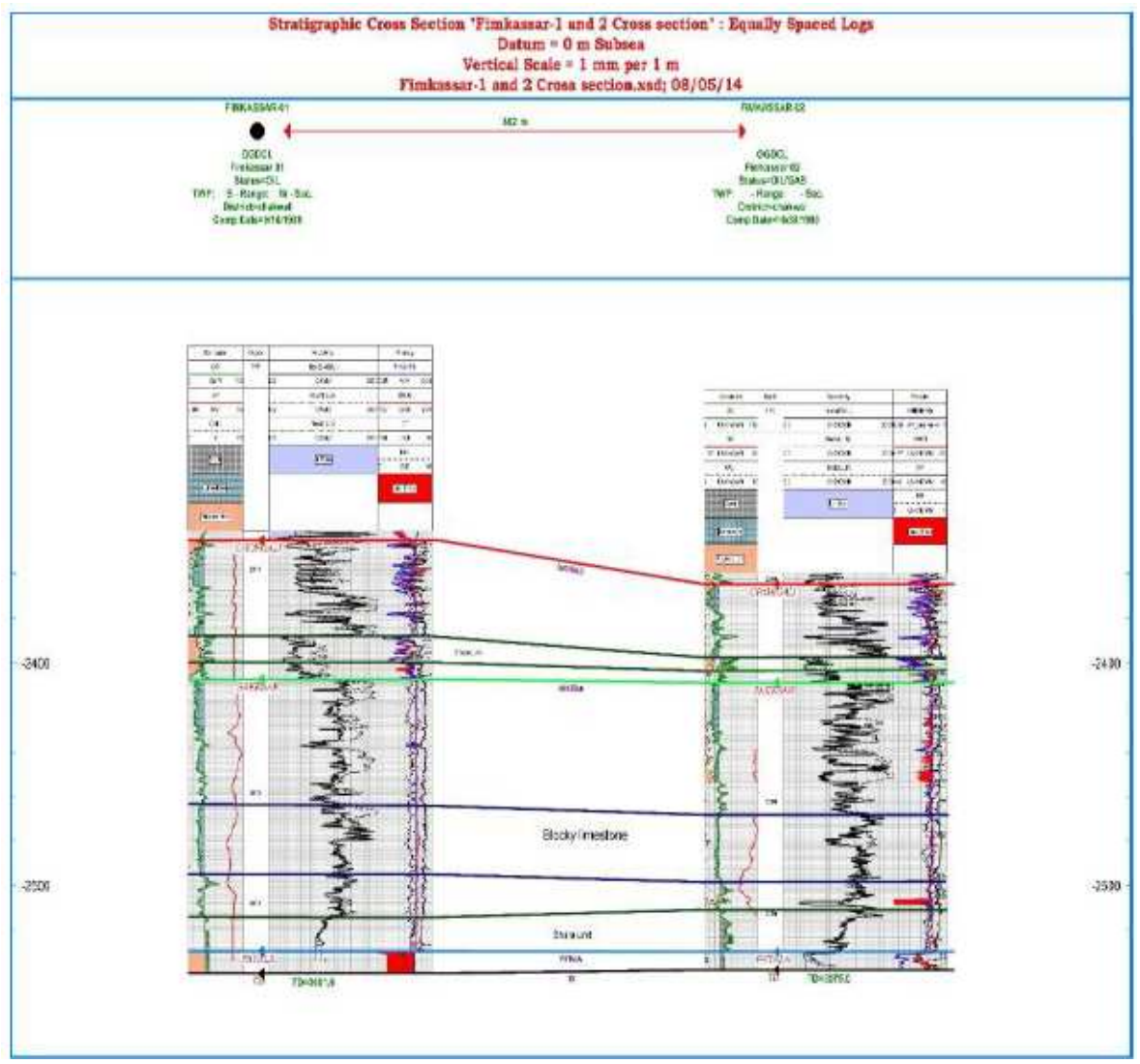

Fig. 14. Well log correlation of Fimkassar well 1 and 2 
Table 1 Depth and area chart for reserve estimation Chorgali depth and area chart

\begin{tabular}{lll}
\hline S.NO & Depth $(\mathrm{m})$ & Area $($ Sq.km) \\
\hline 1 & 2450 & 0.389 \\
2 & 2460 & 1.455 \\
3 & 2470 & 2.861 \\
4 & 2480 & 4.089 \\
5 & 2490 & 5.201 \\
6 & 2500 & 6.235 \\
\hline
\end{tabular}

Table 2. Eserve estimation prospect table for fimkassar oil field Reserve estimation prospect table for fimkassar oil field

\begin{tabular}{|c|c|c|c|c|c|c|c|c|c|}
\hline Name & Unit & Shape & Min & $\mathrm{P} 90$ & $\mathrm{P} 50$ & $\mathrm{P} 10$ & Max & Mod & Mean \\
\hline Thickness & $\mathrm{M}$ & Longnormal & 37.10 & 45.00 & 52.00 & 60.00 & 72.8 & 51.30 & 52.30 \\
\hline Spill poit & M & single & 2500.00 & 2500.00 & 2500.00 & 2500.00 & 2500.00 & 2500.00 & 2500.00 \\
\hline Deg of fill & $\%$ & single & 100.00 & 100.00 & 100.00 & 100.00 & 100.00 & 100.00 & 100.00 \\
\hline Net to Gross & $\%$ & Longnormal & 20.00 & 25.00 & 29.60 & 35.00 & 43.90 & 29.10 & 29.80 \\
\hline Porosity & $\%$ & Longnormal & 3.48 & 6.73 & 11.00 & 18.00 & 34.80 & 9.49 & 11.80 \\
\hline SW & $\%$ & Longnormal & 27.60 & 35.00 & 41.80 & 50.00 & 63.50 & 41.00 & 42.20 \\
\hline NTG (fr) & $\%$ & Longnormal & 14.40 & 18.00 & 21.20 & 25.00 & 31.02 & 20.90 & 21.40 \\
\hline Pro (fr) & $\%$ & Longnormal & 0.23 & 0.40 & 0.60 & 0.90 & 1.55 & 0.54 & 0.63 \\
\hline SW (fr) & $\%$ & Longnormal & 10.70 & 15.00 & 19.40 & 25.00 & 35.20 & 18.60 & 19.80 \\
\hline FVF (B。 $)$ & $\mathrm{vol} / \mathrm{vol}$ & Longnormal & 1.31 & 1.50 & 1.66 & 1.85 & 2.12 & 1.65 & 1.67 \\
\hline Oil rec factor & $\%$ & Longnormal & 12.40 & 15.00 & 17.30 & 20.00 & 24.30 & 17.10 & 17.40 \\
\hline Oil rec fac (fr) & $\%$ & Longnormal & 15.20 & 20.00 & 24.50 & 30.60 & 39.40 & 23.90 & 24.80 \\
\hline Area & Sq.km & $6 \mathrm{Sq} . \mathrm{km}$ & & & & & & & \\
\hline In-place oil & MMSTB & 13.8 MMSTB & & & & & & & \\
\hline Recoverable oil & MMSTB & 2.45 MMSTB & & & & & & & \\
\hline
\end{tabular}

Table 3. Results of reserve estimation

\begin{tabular}{ll}
\hline Reservoir name & Chorgali \\
\hline Reservoir Age & Eocene \\
Field location & District Chakwal \\
Field status & Producing. \\
In Place Oil & 13.8 MMSTB \\
Recoverable Oil & 2.45 MMSTB \\
\hline
\end{tabular}

Reserve estimation program or REP version 5.3 was used for reserve estimation in Fimkassar oil field of Potwar Sub-Basin. The Basic parameter of reserve estimation can be calculated by using computer base tool REP 5.3 which is given in Table 2. The software work on the principle of volumetric method which is also known as geologist method. Put all the parameters in software manually and give command to software. The software process on all parameter and automatically generate formula and complete processing. The result calculated by the software is given Table 3. Eocene Chorgali Reservoir consists of 13.8 MMSTB in place oil and total recoverable oil in Eocene Reservoir is 2.45 MMSTB.

\section{Discussion}

Fimkassar oil field is located at $75 \mathrm{~km}$ away from SW of Islamabad city. Fimkassar Oil Field is the area of Potwar Sub-Basin is bounded by Soan Syncline in north,
Salt Range in south, Jhelum Fault in east and Kalabag Fault in west. Fimkassar Oil Field was discovered in 1980 but it is still operated by OGDCL and give production at recent time. The main producing formation in Fimkassar well\#1 and \#2 is Chorgali Formation. In Fimkassar well\#1 Sakesar Limestone is totally contained water but in Fimkassar well\#2 the Sakesar Limestone consists both of water and hydrocarbon. Fimkassar well\#1 was drilled in 1980 by Gulf Oil Company. The production rate was not good due to low productivity so it was sold to OGDCL. OGDCL again worked on this field and new seismic survey was done by OGDCL. Fimkassar well\#1 was side-tracked and drilled down to $3081 \mathrm{~m}$ with horizontal displacement of $250 \mathrm{~m}$ in March 1989. The well was completed with Sakesar Limestone and initial flow rate of 4100 BOPD and 4MMSCFD in October, 1989. Fimkassar well\#2 was drilled and completed in 1990 and give production at oil and gas flow rate were 1600 BOPD and 1.4 MMSCFD respectely. In the study area Chorgali Formation and Sakesar Limestone act as a reservoir rock and Chorgali Shale and Murree Clays act as seals. Similarly, Patala Formation act as a source rock in the study area. Areal structure shows that anticline is present in study area and seismic section show that triangular zone structure present in Fimkassar Oil Field. The study area consists of reverse faults and at some places back thrusting can 
see so the Potwar Sub-Basin is highly fractured due to tectonic activity. The main reflector marked on the seismic lines of Fimkassar area is Chorgali Formation which is producing hydrocarbon. Petophysical study was done successfully by using GR $\log$, SP $\log$, LLS, LLD, MSFL and ROHB log. The Petrophysical study consists of volume of shale, porosity, lithology identification, resistivity of water, saturation of water and saturation of hydrocarbon. The seismic and petrophysical analysis result were used to calculate reserve estimation in Fimkassar Oil Field with the help of volumetric method. Seismic, petrophysical and reserve estimation analysis in Fimkassar Oil Field show that this oil field has a considerable amount of hydrocarbon. This field has a great potential to serve the recent and future energy requirements of Pakistan.

\section{Conclusion}

Five lines were used for seismic study and Depth and sonic log data can be used to generate synthetic seismogram to mark accurate horizons on seismic section and match with stratigraphic column. The horizons marked on seismic section are Chorgali Formation, Sakesar Limestone and Patala Formation. Reverse fault are marked in the study area. The structure in the study area is triangular zone which is act as a trap in the study area and is suitable for drilling oil well. Time structure and depth contour map is used to confirm the structure of the study area. The time structure map show that area is structurally fault bounded from southeast and three-way closure toward NW-SE side.

The petrophysical analysis of the zone of interest is marked in Chorgali Formation and Sakesar formation, but after analysis it is concluded that Chorgali Formation is reservoir zone for hydrocarbon potential. The lithology of the Chorgali Formation is shale and limestone in reservoir area. Petrophysical analysis shows that in Fimkassar well 01 volume of shale is $21 \%$, porosity is $13 \%$ and water saturation is $53 \%$ similarly in Fimkassar well 02 volume of shale is $24 \%$, porosity is $16 \%$ and water saturation is $44 \%$. Petrophysical analysis show that Chorgali Formation is acting as a good hydrocarbon potential bearing rock. Pay zone thickness in Fimkassar well 01 is $11.31 \mathrm{~m}$ and similarly in Fimkassar well 02 it is $8.63 \mathrm{~m}$. Oil-water contact marked in Fimkassar well 01 is at $2957 \mathrm{~m}$ depth and below this depth no oil is present in the well where as in Fimkassar well 02 it is marked at a depth of $2992 \mathrm{~m}$ and below this oil and water both are present in Sakesar Formation.

The seismic and petrophysical parameters are used for reserve estimation technique it is concluded that Eocene Chorgali Reservoir contains is 13.8 MMSTB in place oil and total recoverable oil in Eocene Reservoir is 2.45 MMSTB.

\section{Acknowledgement}

I am special thanks to directorate general of petroleum concession (DGPC) and land mark resources (LMKR) Islamabad Pakistan for providing the data.

\section{Funding Information}

The funding source is the University of Azad Jammu and Kashmir, Muzaffarabad, Pakistan.

\section{Author's Contributions}

Muhammad Ishfaque: Data collection, data analysis and data interpretation.

Hafeez Ur Rehman: Final formatting, data collection.

Bilal Khalid: Digitized Map.

Syed Habib: Result finalization

Umair Fakhar: Data collection.

Sudip Chakarborti: Manuscript organization and review.

\section{Ethics}

This article is original and contains unpublished material. The corresponding author confirms that all of the other authors have read and approved the manuscript and no ethical issues involved in this manuscript.

\section{References}

Aamir, M. and M.M. Siddiqui, 2006. Interpretation and visualization of thrust sheets in a triangle zone in Eastern Potwar, Pakistan. Lead. Edge, 25: 24-37. DOI: DOI: 10.1190/1.2164749

Archie, G.E., 1942. The electrical resistivity log as an aid in determining some reservoir characteristics. Trans. AIME, 146: 54-62. DOI: 10.2118/942054-G

Buryakovsky, 1., G.V. Chilingar, H. Rieke and S. Shin, 2012. Fundamentals of the Petrophysics of Oil and Gas Reservoirs. 1st Edn., John Wiley and Sons, Beverly, ISBN-10: 1118472721, pp: 400.

Dobrin, M.B. and C.H. Savit, 1988. Introduction to Geophysical Prospecting. 4th Edn., McGraw Hill Company, New York, ISBN-10: 0070171963, pp: 867.

Evenick, J., 2008. Introduction to Well Logs and Subsurface Maps. 1st Edn., PennWell Books, Tulsa, ISBN-10: 1593701381, pp: 236.

Hilchie, W.D., 1978. Applied open hole log interpretation for geologist and engineer. Hilchie W.D. Inc., Golden, Colorado.

Khalid, P., Q. Yasin, G.M.D. Sohail and J.M. Kashif, 2015. Integrating core and wireline $\log$ data to evaluate porosity of Jurassic Formations of injra-1 and nuryal-2 wells, western Potwar, Pakistan. J. Geol. Society India, 86: 553-562.

DOI: $10.1007 / \mathrm{s} 12594-015-0346-9$ 
Moghal, M.A., A. Hameed, M.I. Saqi and M.N. Bugti, 2007. Subsurface geometry of Potwar sub-basin in relation to structuration and entrapment. Pak. J. Hydroc Res, 17: 61-72.

Rider, M.H., 2002. The Geological Interpretation of Well Logs. 2nd Edn., Rider-French Consulting, Rogart, ISBN-10: 0954190602, pp: 280.
Schlumberger, 1974. Log Interpretation Principles. 1st Edn., Schlumberger Education Services, Houston, TX., pp: 230.

Wyllie, M.R.J., A.R. Gregory and G.H.F. Gardner, 1958. An experimental investigation of factors affecting elastic wave velocities in porous media. Geophysics, 23: 459-493. DOI: 10.1190/1.1438493 